\title{
EXPLORING SIROLIMUS PHARMACOKINETIC VARIABILITY USING DATA AVAILABLE FROM THE ROUTINE CLINICAL CARE OF RENAL TRANSPLANT PATIENTS - POPULATION PHARMACOKINETIC APPROACH
}

\author{
ISTRAŽIVANJE FARMAKOKINETIČKE VARIJABILNOSTI SIROLIMUSA NA OSNOVU \\ PODATAKA DOBIJENIH STANDARDNIM, RUTINSKIM, KLINIČKIM PRAĆENJEM PACIJENATA \\ SA TRANSPLANTIRANIM BUBREGOM - POPULACIONI FARMAKOKINETIČKI PRISTUP
}

\author{
Bojana Golubović1, Katarina Vučićević ${ }^{1}$ Dragana Radivojević2, Sandra Vezmar Kovačević1, \\ Milica Prostran ${ }^{3}$, Branislava Miljković ${ }^{1}$ \\ ${ }^{1}$ Department of Pharmacokinetics and Clinical Pharmacy, University of Belgrade-Faculty of Pharmacy, \\ Belgrade, Republic of Serbia \\ ${ }^{2}$ Nephrology Clinic, Clinical Center of Serbia, University of Belgrade, Belgrade, Republic of Serbia \\ ${ }^{3}$ Department of Pharmacology, Clinical Pharmacology and Toxicology, \\ University of Belgrade-School of Medicine, Belgrade, Republic of Serbia
}

\begin{abstract}
Summary
Background: Due to wide intra- and inter-individual pharmacokinetic variability and narrow therapeutic index of sirolimus, the therapeutic drug monitoring (TDM) of sirolimus with detailed biochemical and clinical monitoring is necessary for dose individualization in kidney transplant patients. The purpose of the study was to explore and identify factors that contribute to pharmacokinetic variability by developing and validating a population model using routine TDM data and routinely monitored biochemical and clinical parameters.

Methods: The data obtained by routine monitoring of 38 patients over a period of one year from the sirolimus treatment initiation, were collected from patients' records. Population analysis was performed using the software NONMEM $^{\circledR}$. The validity of the model was tested by the internal and external validation techniques.

Results: The pharmacokinetic variability was partially explained with patient's age and liver function. CL/F was found to decrease with age. According to the developed model, sirolimus CL/F decreases by, in average, $37 \%$ in
\end{abstract}

Address for correspondence:

Bojana Golubović, M Pharm

Department of Pharmacokinetics and Clinical Pharmacy,

University of Belgrade-Faculty of Pharmacy

Vojvode Stepe 450, 11221 Belgrade, Serbia

Tel: +381 113951373 , fax: +381113972840

e-mail: bojanap@pharmacy.bg.ac.rs

\begin{abstract}
Kratak sadržaj
Uvod: Terapijski monitoring sirolimusa, uz intenzivno praćenje biohemijskih i kliničkih parametara, neophodni su kako bi se doza leka mogla individualno prilagoditi svakom pacijentu sa transplantiranim bubregom. Individualizacija režima doziranja sirolimusa neophodna je zbog velike intrai inter-individualne farmakokinetičke varijabilnosti i malog terapijskog indeksa leka. Cilj ovog istraživanja bilo je proučavanje i identifikacija faktora koji mogu objasniti varijabilnost u farmakokinetici, kao i da se, na osnovu rutinski praćenih biohemijskih i kliničkih parametara i koncentracija sirolimusa, razvije i validira populacioni farmakokinetički model.

Metode: Podaci dobijeni rutinskim praćenjem 38 pacijenata $u$ periodu od godinu dana nakon otpočinjanja primene sirolimusa sakupljeni su iz medicinskih kartona. Populaciona analiza je urađena primenom kompjuterskog programa NONMEM ${ }^{\circledR}$. Razvijeni model je validiran primenom internih i eksternih tehnika validacije.

Rezultati: Varijabilnost u farmakokinetici je delimično objašnjena uticajem godina i funkcije jetre. Pokazano je da
\end{abstract}

List of abbreviations: 1-COMP, one compartmental model; 2COMP, two compartmental model; AIC, Akaike information criterion; ALP, alkaline phosphatase; ALT, alanine aminotransferase; AST, aspartate aminotransferase; BIC, Bayesian information criterion; $\mathrm{CHOL}$, cholesterol; $\mathrm{Cl}$, confidence interval; $\mathrm{CL} / \mathrm{F}$, apparent clearance; CORT, corticosteroids; CWRES, conditional weighted residuals; DIAL, dialysis before transplantation; GEND, gender; GRFT, graft origin; HCT, hematocrit; HGB, hemoglobin; $k_{a}$ ' 
patients with aspartate aminotransferase (AST) greater than $37 \mathrm{IU} / \mathrm{L}$. The internal and external validation confirmed the satisfactory prediction of the developed model. Conclusions: The population modeling of routinely monitored data allowed quantification of the age and liver function influence on sirolimus $\mathrm{CL} / \mathrm{F}$. According to the final model, patients with compromised liver function expressed via AST values require careful monitoring and dosing adjustments. Proven good predictive performance makes this model a useful tool in everyday clinical practice.

Keywords: aspartate aminotransferase, kidney transplantation, pharmacokinetics, sirolimus, therapeutic drug monitoring

\section{Introduction}

Effective immunosuppression plays a crucial role in the successful post-transplantation period. Sirolimus, immunosuppressive which inhibits the cellular response to IL-2 and T-cell proliferation, is approved for the prevention of organ rejection in kidney transplant patients (1-4). Sirolimus is characterized by highly variable absorption and elimination which result in substantial blood concentrations differences among patients receiving the same doses (5). Due to wide intra- and inter-individual pharmacokinetic variability and narrow therapeutic index of sirolimus, therapeutic drug monitoring and dose individualization are necessary $(1,5)$. Therefore, TDM and detailed biochemical and clinical monitoring represent the cornerstone of the transplant patients'care. Finding, explaining and quantifying the potential factors of pharmacokinetic variability in individual patient would make dose individualization more effective. Population approach could enable this.

Numerous sources of pharmacokinetic variability have been recognized in the conventional pharmacokinetic studies of sirolimus (8-15). Results of these studies suggest the influence of age, food, hepatic impairment and race on sirolimus pharmacokinetic parameters $(4,8,12-15)$. In contrast, only a few population studies have been conducted to assess the pharmacokinetics of sirolimus in kidney transplant patients (16-19). Those studies quantified the influence of age (17), CYP3A5 polymorphism (19), sirolimus dose, total cholesterol and cyclosporine, silymarin and glycyrrhizin co-therapy on specific pharmacokinetic parameters (18). Aforementioned population pharmacokinetic studies of sirolimus in kidney

absorption rate constant; MMF, mycophenolatemofetil; MPE, mean prediction error; NPC, numerical predictive check; OFV, objective function value; PRED, population predictions; pvcVPC, prediction- and variability-corrected visual predictive check; Q/F, apparent intercompartmental clearance; RMSPE, root mean squared prediction error; SD, standard deviation; se $\mathrm{CL} / \mathrm{F}$ sirolimusa smanjuje sa starošću. Prema razvijenom modelu, CL/F sirolimusa se smanjuje za, u proseku, 37\% kod pacijenata kod kojih je aspartat aminotransferaza (AST) povećana (granična vrednost $37 \mathrm{IU} / \mathrm{L}$ ). Interna i eksterna validacija su potvrdile zadovoljavajuću prediktabilnost razvijenog modela.

Zaključak: Populaciono modelovanje podataka dobijenih rutinskim praćenjem pacijenata omogućilo je kvantifikaciju uticaja godina i funkcije jetre pacijenata na CL/F sirolimusa. Prema razvijenom modelu, pacijenti sa kompromitovanom funkcijom jetre trebaju biti pažljivije praćeni uz odgovarajuće prilagođavanje doze sirolimusa. Dokazana dobra prediktabilnost ovog modela čini ga korisnim u individualizaciji doze sirolimusa u svakodnevnoj kliničkoj praksi.

Ključne reči: aspartat aminotransferaza, transplantacija bubrega, sirolimus, terapeutsko praćenje lekova

transplant patients had different designs and sampling schedules. Heretofore, population pharmacokinetic models of sirolimus were based on full population pharmacokinetic sampling design or planned sampling of trough concentrations. To our knowledge, only one model was developed from routine clinical data, however, blood samples in that study were not only trough (7), which is recommended during sirolimus TDM (2). Developing population pharmacokinetic model based on TDM data and routinely monitored biochemical and clinical parameters could be a valuable tool in everyday clinical practice and sirolimus dosing. Therefore, the purpose of our study was to explore, identify factors and quantify their contribution to sirolimus pharmacokinetic variability by developing population pharmacokinetic model using TDM trough data, as well as to validate and investigate the predictability of developed model.

\section{Materials and Methods}

\section{Patients and data collection}

This retrospective study was conducted on all adult kidney transplant recipients from the Nephrology Clinic, Clinical Center of Serbia, treated with sirolimus from March 2012 to December 2013. Patients were informed about the study and agreed to participate. Following patients' data were collected from the medical charts: gender, age, body weight, graft origin, dialysis before transplantation, serum creatinine, hematocrit, hemoglobin, total proteins, cholesterol, triglycerides, alanine aminotransferase, aspartate aminotransferase, alkaline phosphatase levels, sirolimus daily dose and concomitant immuno-

SE, standard error; SECR, serum creatinine; TDM, therapeutic drug monitoring; TP, total proteins; TRIG, triglycerides; $\mathrm{Vc} / \mathrm{F}$, apparent central volume of distribution; $\mathrm{Vd} / \mathrm{F}$, apparent volume of distribution; $\mathrm{Vp} / \mathrm{F}$, apparent volume distribution of peripheral compartment; $\mathrm{Wa}$, additive error; $\mathrm{Wp}$, proportional error; WT, body weight; $\omega^{2}$, variance. 
suppressive drug doses. Patients were treated with triple immunosuppressive therapy that included sirolimus, mycophenolatemofetil and corticosteroids. According to the local protocol, sirolimus represents the second line post-transplantation immunosuppressive treatment. Hence, all patients in the study were converted to sirolimus from either tacrolimus or cyclosporine. The recommended dose of sirolimus on the first day was $12-20 \mathrm{mg}$ per day with simultaneous discontinuation of calcineurin inhibitor therapy and 4$8 \mathrm{mg}$ per day starting from the second to the fifth day. Subsequent dosing regimens of sirolimus were guided to achieve trough blood concentrations of 8-20 $\mathrm{ng} / \mathrm{mL}$ together with a clinical evidence of efficacy and safety. Data collected from all patients were used for model developing. Afterwards, we collected data from novel sirolimus-treated patients for model evaluation (external data set).

\section{Blood sampling and bioanalytical assay}

All blood samples were obtained as a part of the TDM protocol. Blood samples were collected at the end of the dosing interval, before the morning dose in all patients, thus measured sirolimus concentrations corresponded to trough levels.

Concentrations of sirolimus in whole blood were assessed using Architect Sirolimus assay ${ }^{\circledR}$ (Abbott Laboratories), a chemiluminescentmicroparticle immunoassay (20). Concentrations were measured in line with manufacturer's instructions. According to the package insert, reported measurement range is $2-30 \mathrm{ng} / \mathrm{mL}$. Blood samples exceeding this range were diluted according to the manufacturer's protocol (20).

\section{Compliance with ethical standards}

Approval for the study was obtained from the Ethics Committee of Clinical Center of Serbia, University of Belgrade (number of decision 2724/4 from 23.02.2012.).

\section{Population pharmacokinetic modeling}

Population pharmacokinetic analysis was performed using software NONMEM ${ }^{\circledR}$ (ver. 7.3) (21). Perl-speaks-NONMEM $(\mathrm{PsN})^{\circledR}$ (ver. 4.4.0), Xpose ${ }^{\circledR}$ (ver. 4.5.3), $\mathrm{R}^{\circledR}$ (ver. 3.2.1) and Pirana ${ }^{\circledR}$ (ver. 2.9.1) were used as auxiliary software tools for model development, evaluation and graphical presentation (22). The first-order conditional estimation method with interaction was used for parameters estimation. A one-compartment pharmacokinetic model with firstorder absorption and elimination (1-COMP) and twocompartment model with first-order absorption and elimination were tested as structural models. Parameters' values not expected to be estimated with sat- isfied certainty were fixed on literature values or informative priors were used for parameters and their variability. Prior information was incorporated into the models using NONMEM prior functionality $(21,23)$. The 1-COMP model was tested with fixed volume of distribution $(\mathrm{Vd} / \mathrm{F})$ and absorption rate constant $\left(\mathrm{k}_{\mathrm{a}}\right)$ on literature values and with use of priors for these parameters and their variabilities. The 2-COMP model was tested with use of priors for $k_{a}$, central volume of distribution $(\mathrm{Vc} / \mathrm{F})$, volume distribution of peripheral compartment $(\mathrm{Vp} / \mathrm{F})$, intercompartmental clearance $(\mathrm{Q} / \mathrm{F})$ and their variabilities. Informative priors for 1-COMP were used from Jiao et al. (17), while for 2-COMP results of Dansirikul et al. (17) were utilized (18). Since in the study of Jiao et al. (17) $k_{a}$ was fixed, we used the same value for this parameter and its interindividual variability as in 2-COMP. Interindividual variability was evaluated by an exponential model. For residual unexplained variability of sirolimus concentration, the additive, the proportional, and the slope-intercept error models were tested. In the second step, we explored the effects of covariates on sirolimus $C L / F$ interindividual variability. Models used for testing covariates were linear, power and exponential. Tested continuous covariates were WT, AGE, SECR, HCT, TP, CHOL, TRIG, ALP, AST, ALT, $M M F$ and CORT, while laboratory parameters including SECR, CHOL, TRIG and AST were tested as categorical covariates as well. The transformation of continuous covariate data to categorical was done according to the clinical definition of normal versus elevated levels. GEND, GRFT and DIAL were investigated as categorical covariates. Missing covariate data for HCT (1.6\%) and TP (7.6\%) were treated with multiple imputations of the median values. An imputation method for missing data for $\mathrm{CHOL}(22.4 \%)$, TRIG (22.4\%), ALP (12.8\%), AST (12\%) and ALT $(12.4 \%)$ was last-observation carried forward (LOCF) $(24,25)$. Covariates were introduced sequentially into the population models to develop a full model. In each step of the covariate model building, the covariate with the highest drop in objective function value (OFV), at least $3.84(p<0.05)$, was included in the model. The full model was obtained when the effects of all the remaining covariates were insignificant (OFV < 3.84). The final model was determined by backward elimination of the insignificant covariates from the full model. The criteria used for retaining a covariate was an increase in OFV of at least $6.63(p<$ 0.01). An additional criterion for the retention of a covariate in the model was reduction in unexplained interindividual variability $(21,26)$.

\section{Model evaluation}

The tested structural models were compared by Akaike information criterion and Bayesian information criterion (27). The model with the lowest AIC and $\mathrm{BIC}$ value is considered to be superior to others. 
The developed model was evaluated with internal and external validation techniques. The accuracy and robustness of the final population model were further assessed by a nonparametric bootstrap of 1000 samples (28). The predictive performance of the final model was additionally assessed by numerical predictive check and prediction- and variabilitycorrected visual predictive check ( $p v \mathrm{VPC}$ ) based on 1000 simulations $(29,30)$. The developed final model from the original dataset was used to predict sirolimus concentrations for validation group of patients, given their demographic characteristics and dosing history. Statistical analysis was done in IBM SPSS Statistics ${ }^{\circledR}$ (ver. 22). Bias was estimated by calculating the mean prediction error and its $95 \%$ confidence interval $(\mathrm{Cl})(31)$. The $95 \% \mathrm{Cl}$ including the value of zero was considered unbiased (31). The root mean squared prediction error was used to assess precision (31).

\section{Results}

Data for modeling consisted of 250 trough sirolimus concentrations, from 25 patients, collected retrospectively, over a period of one year from the sirolimus treatment initiation. 13 patients who were in the post-modeling period converted to sirolimus (1-2 measured concentrations per patient) were included in the validation group. Patients' characteristics are presented in Table I. Initially, we evaluated 1-COMP model with fixed parameters values and using priors, as well as 2-COMP model with use of priors.2-COMP model with use of priors is chosen as structural model based on the favorable AIC and BIC values (Table II). The residual variability was best described with slopeintercept error model.

The most significant decrease in OFV, in a forward model building step, produced the inclusion of AST as categorical covariate. Preliminary analysis of covariate correlation showed significant correlation among AST, ALT, ALP (0.605 < r <0.805). To avoid the collinearity, and taking into account that AST produced more significant decrease in OFV compared to

Table I Patients' demographic, biochemical and immunosuppressive therapy characteristics.

\begin{tabular}{|c|c|c|c|c|c|}
\hline \multirow{2}{*}{\multicolumn{2}{|c|}{ Characteristic }} & \multicolumn{2}{|c|}{ Data used in model development } & \multicolumn{2}{|c|}{ Data used in external validation } \\
\hline & & $\begin{array}{l}\text { Number (\%) / } \\
\text { Mean } \pm \text { SD }\end{array}$ & Range & $\begin{array}{l}\text { Number (\%) / } \\
\text { Mean } \pm S D\end{array}$ & Range \\
\hline \multicolumn{2}{|c|}{ Sex (Male / Female) } & $18(72) / 7(28)$ & & $9(69) / 4(31)$ & \\
\hline \multicolumn{2}{|c|}{ Graft origin (Living donor / Cadaver) } & $23(92) / 2(8)$ & & $11(85) / 2(15)$ & \\
\hline \multicolumn{2}{|c|}{$\begin{array}{l}\text { Dialysis before } \\
\text { transplantations (Yes / No) }\end{array}$} & $21(84) / 4(16)$ & & $11(85) / 2(15)$ & \\
\hline \multicolumn{2}{|c|}{ Age (years) } & $43.22 \pm 12.62$ & $16-64$ & $40.38 \pm 10.18$ & $18-59$ \\
\hline \multicolumn{2}{|c|}{ Body weight $(\mathrm{kg})$} & $77.07 \pm 18.76$ & $44-128$ & $74.62 \pm 16.71$ & $54-110$ \\
\hline \multicolumn{2}{|c|}{ Serum creatinine $(\mu \mathrm{mol} / \mathrm{L})$} & $194.86 \pm 60.85$ & $75-437$ & $195.09 \pm 38.61$ & $129-264$ \\
\hline \multicolumn{2}{|c|}{ Haemoglobin (g/L) } & $112.75 \pm 16.45$ & $67-155$ & $117.33 \pm 17.88$ & $89-151$ \\
\hline \multicolumn{2}{|c|}{ Haematocrit } & $0.33 \pm 0.05$ & $0.18-0.83$ & $0.34 \pm 0.05$ & $0.26-0.43$ \\
\hline \multicolumn{2}{|c|}{ Proteinaemia $(\mathrm{g} / \mathrm{L})$} & $69.25 \pm 6.31$ & $44-83$ & $69.71 \pm 7.45$ & $45-79$ \\
\hline \multicolumn{2}{|c|}{ Total cholesterol (mmol/L) } & $6.15 \pm 1.22$ & $2.62-9.45$ & $6.76 \pm 1.1$ & $5.13-8.98$ \\
\hline \multicolumn{2}{|c|}{ Triglycerides (mmol/L) } & $2.55 \pm 1.09$ & $0.73-6.64$ & $2.53 \pm 1.39$ & $1.35-7.67$ \\
\hline \multicolumn{2}{|c|}{ Alkaline phosphatase (IU/L) } & $74.94 \pm 32.37$ & $30-226$ & $79.09 \pm 34.08$ & $32-178$ \\
\hline \multicolumn{2}{|c|}{ Aspartate aminotransferase (IU/L) } & $28.34 \pm 28.78$ & $9-274$ & $22.09 \pm 13.42$ & $10-74$ \\
\hline \multicolumn{2}{|c|}{ Alanine aminotransferase (IU/L) } & $31.17 \pm 29.54$ & $7-226$ & $26.24 \pm 16.19$ & $6-81$ \\
\hline \multirow{2}{*}{ Sirolimus } & Dose (mg/day) & $3.6 \pm 2.36$ & $0.5-15$ & $4.26 \pm 3.62$ & $1-14$ \\
\hline & Trough concentration $(\mathrm{ng} / \mathrm{mL})$ & $9.85 \pm 4.81$ & $0.5-38.4$ & $8.69 \pm 2.64$ & $4.9-16$ \\
\hline \multicolumn{2}{|c|}{ Mycophenolatemofetil dose (mg/day) } & $1104 \pm 439.84$ & $0-2000$ & $1250 \pm 454.15$ & $0-2000$ \\
\hline \multicolumn{2}{|c|}{ Corticosteroids dose (mg/day) } & $10.74 \pm 6.5$ & $0-50$ & $8.45 \pm 3.49$ & $0-15$ \\
\hline
\end{tabular}

SD - standard deviation. 
Table II Characteristics of tested structural models.

\begin{tabular}{|l|c|c|c|c|}
\hline Model & OFV & AIC & BIC & Comment \\
\hline $\begin{array}{l}\text { 1-compartment } \\
\text { with fixed } \\
\text { parameters values }\end{array}$ & 933.4 & 945.8 & 966.6 & \\
\hline $\begin{array}{l}\text { 1-compartment } \\
\text { with prior } \\
\text { parameters values }\end{array}$ & 903.8 & 919.8 & 947.9 & $\begin{array}{l}\text { Zero gradients } \\
\text { were } \\
\text { encountered }\end{array}$ \\
\hline $\begin{array}{l}\text { 2-compartment } \\
\text { with prior } \\
\text { parameters values }\end{array}$ & 384.0 & 408.0 & 450.3 & \\
\hline
\end{tabular}

OFV - objective function value; AIC -Akaike information criterion; BIC - Bayesian information criterion.

Table III Model building process.

\begin{tabular}{|c|c|c|c|c|}
\hline & & $\begin{array}{c}\text { Covariate } \\
\text { (tested model) }\end{array}$ & OFV & $\Delta \mathrm{OFV}^{\mathrm{a}, \mathrm{b}}$ \\
\hline \multicolumn{3}{|c|}{ Base model } & 384.0 & \\
\hline \multirow{7}{*}{ 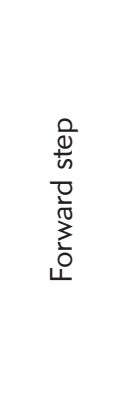 } & \multirow{5}{*}{1} & AST (categorical) & 353.3 & 30.7 \\
\hline & & AST (linear) & 378.4 & 5.6 \\
\hline & & AST (power) & 377.7 & 6.3 \\
\hline & & AGE (linear) & 373.8 & 10.2 \\
\hline & & MMF (linear) & 377.6 & 6.4 \\
\hline & Submodel 1 & AST (categorical) & 353.3 & \\
\hline & 2 & AGE (linear) & 346.7 & 6.6 \\
\hline \multicolumn{3}{|l|}{ Full model } & 346.7 & \\
\hline \multirow{2}{*}{$\begin{array}{l}\text { Backward } \\
\text { step }\end{array}$} & \multicolumn{2}{|c|}{ Without AST } & 373.8 & 27.1 \\
\hline & \multicolumn{2}{|c|}{ Without AGE } & 353.3 & 6.6 \\
\hline
\end{tabular}

a $\triangle$ OFV for forward model was calculated compared to OFV of the previous submodel; ${ }^{b}-\triangle O F V$ for backward step was calculated compared to OFV of the full model; OFV, objective function value; MMF, mycophenolate mofetil dose; AST, aspartate aminotransferase.

ALT and ALP, this covariate was selected for further model development. In the next forward step, age was included in the model. Further inclusion of other covariates did not produce significant decrease in OFV. In the backward elimination step both covariates, age and AST greater than $37 \mathrm{IU} / \mathrm{L}$, were retained in the model. Details of covariate significance during model building process are given in Table III. The final model for sirolimus $\mathrm{CL} / \mathrm{F}$ is described by the following equation:

$$
C L / F=12.2 \times 0.63^{A S T} \times\left(1-\frac{\text { age }}{44} \times 0.388\right),
$$

where AST is 0 if AST is less or equal to $37 \mathrm{IU} / \mathrm{L}$, or 1 if AST is greater than $37 \mathrm{IU} / \mathrm{L}$.

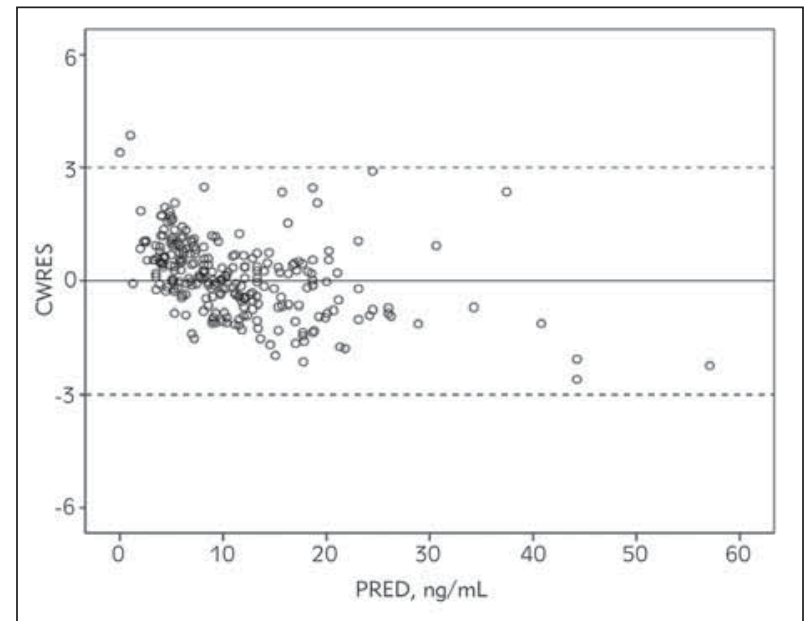

Figure 1 Diagnostic plot conditional weighted residuals (CWRES) versus population predictions (PRED) for the final model.

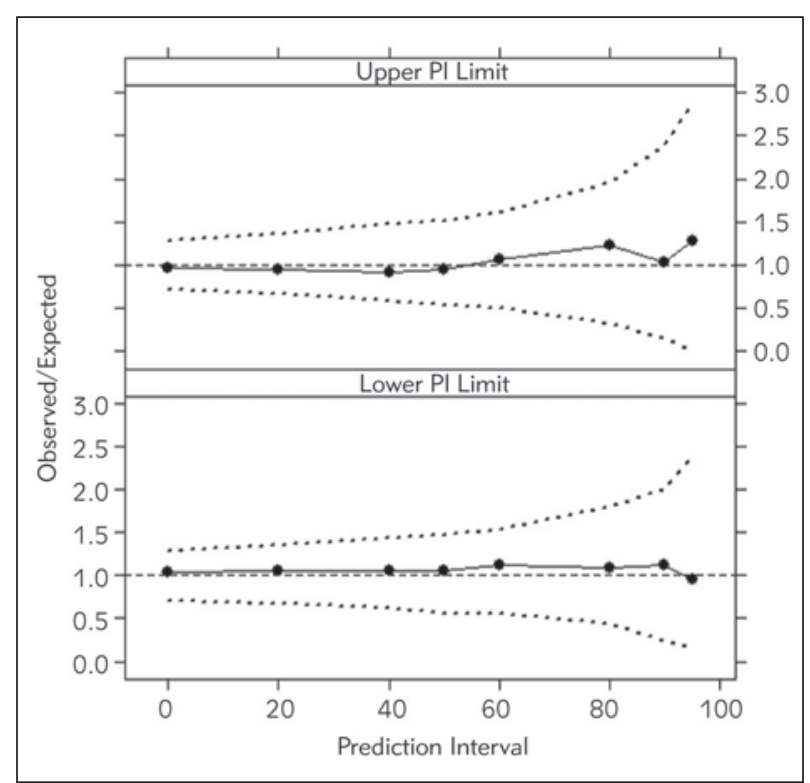

Figure 2 Numerical predictive check of the final population model for sirolimus. Circles present lower and upper limits of prediction intervals (\%) observed in the data. Dashed lines indicate $95 \% \mathrm{Cls}$ of the lower and upper limits of simulationbased prediction intervals (\%).

According to the diagnostic plot CWRES vs. PRED (Figure 1) developed model seems adequate. The final population model parameters estimates and standard errors of the estimates (SE) are presented in Table IV. The bootstrap parameters estimates, based on 995 successful runs out of 1000 scheduled, were not statistically different from the estimates previously obtained with the original dataset.

The predictive performance was satisfactory according to both internal validation techniques (Figures 2 and 3). 
Table IV Parameters estimates and bootstrap results for the final model.

\begin{tabular}{|c|c|c|c|c|}
\hline \multirow{2}{*}{ Parameter } & \multicolumn{2}{|c|}{ Final Model } & \multicolumn{2}{|c|}{ Bootstrap } \\
\hline & Estimate & SE & Median & $95 \% \mathrm{Cl}$ \\
\hline $\mathrm{Q} / \mathrm{F}(\mathrm{L} / \mathrm{h})$ & 5.07 & 2.48 & 5.55 & $2.43-23.4$ \\
\hline$V_{c} / F(L)$ & 118 & 2.54 & 117 & $112-121$ \\
\hline$V_{p} / F(L)$ & 609 & 38.7 & 608 & $530-673$ \\
\hline ka $(1 / h)$ & 2.19 & $4.79 \cdot 10^{-5}$ & 2.19 & $2.19-2.19$ \\
\hline $\mathrm{CL} / \mathrm{F}(\mathrm{L} / \mathrm{h})$ & 12.2 & 2.54 & 12.5 & $8.54-21.2$ \\
\hline AST > $37 \mathrm{IU} / \mathrm{L}^{\mathrm{a}}$ & 0.630 & 0.0548 & 0.626 & $0.550-2.12$ \\
\hline $\mathrm{AGE}^{\mathrm{a}}$ & -0.388 & 0.117 & -0.386 & $-0.551--0.0277$ \\
\hline $\mathrm{Wa}(\mathrm{ng} / \mathrm{mL})^{\mathrm{b}}$ & 1.93 & 0.263 & 1.92 & $0.316-2.38$ \\
\hline$W_{p}^{b}$ & 0.249 & 0.032 & 0.251 & $0.161-0.316$ \\
\hline$\omega^{2} \mathrm{Q} / \mathrm{F}^{\mathrm{c}}$ & 0.103 & $4.79 \cdot 10^{-4}$ & 0.103 & $0.102-0.104$ \\
\hline$\omega^{2} V_{c} / F^{c}$ & 0.306 & 0.00271 & 0.306 & $0.301-0.316$ \\
\hline$\omega^{2} V_{p} / F^{c}$ & 0.0657 & $2.82 \cdot 10^{-4}$ & 0.0656 & $0.0650-0.0669$ \\
\hline$\omega^{2} \mathrm{ka}^{\mathrm{c}}$ & 0.145 & $1.28 \cdot 10^{-6}$ & 0.145 & $0.144-0.144$ \\
\hline$\omega^{2} \mathrm{CL} / \mathrm{F}^{\mathrm{c}}$ & 0.0547 & 0.0177 & 0.0549 & $0.0171-0.114$ \\
\hline
\end{tabular}

a-fixed effects for the relationship between $\mathrm{CL} / \mathrm{F}$ and covariates; ${ }^{\mathrm{b}}$ - residual variability ( $\mathrm{Wa}$ - additive error, $\mathrm{Wp}$ - proportional error);

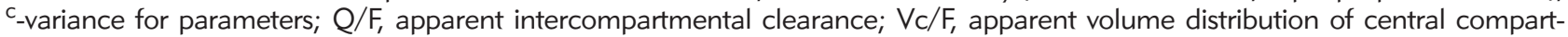
ment; $\mathrm{Vp} / \mathrm{F}$, apparent volume distribution of peripheral compartment; $\mathrm{k}_{\mathrm{a}}$, absorption rate constant; $\mathrm{CL} / \mathrm{F}$, apparent clearance; $\mathrm{SE}$, standard error; $\mathrm{Cl}$, confidence interval.

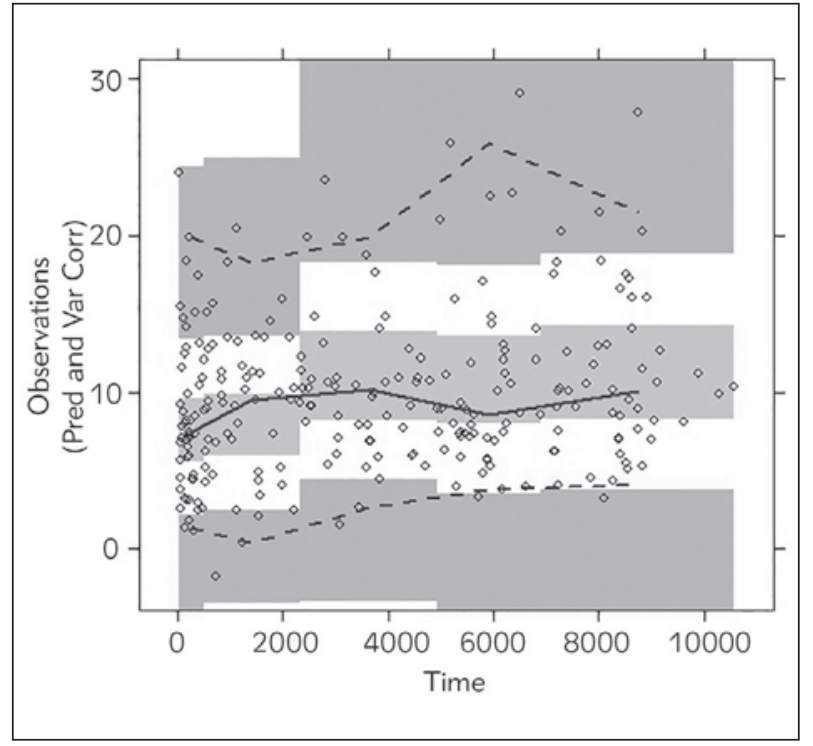

Figure 3 Prediction- and variability-corrected visual predictive check (pvcVPC), prediction- and variability-corrected concentrations $(\mathrm{ng} / \mathrm{mL}$ ) versus time $(\mathrm{h})$ for the final model. Solid and dashed lines represent the median, $5^{\text {th }}$ and $95^{\text {th }}$ percentiles of the observed data with shaded confidence intervals of the prediction intervals for the simulated prediction intervals.
Estimated MPE was $-1.77 .95 \% \mathrm{Cl}$ for MPE (-3.81 - 0.25) included zero so model could be considered as unbiased. As RMSPE decreases, the precision of the model increases. With RMSPE $(95 \% \mathrm{Cl})$ of 4.71 $(2.71-6.08)$ precision of this developed model is satisfactory.

\section{Discussion}

This study represents the population pharmacokinetic analysis of sirolimus in adult kidney transplant patients. All observations included in our study were obtained during routine TDM process, and they were measured before the next dose in steady-state. To our knowledge, this is the first study using only routine monitored data. The similar design was in the study by Dansirikul et al. but sampling times were in range of 1.6 - $77 \mathrm{~h}$ post-dose (17). The concentration-time data were the best described with the 2-COMP model with the use of informative priors. Steady-state through concentrations are rather uninformative, and they permit only estimation of $\mathrm{CL} / \mathrm{F}$ based on 1COMP model. However, sirolimus pharmacokinetic profile is better described by 2-COMP model $(5,16$, 19). Nevertheless, applying more complex pharmacokinetic model to fit sirolimus concentration-time 
data was more appropriate for data analysis in our study (Table II). The use of informative priors, through method based on and similar to Bayesian approach, was shown as superior way of incorporating external information compared to fixing parameters to single values. Similar results in choosing structural model, but using Bayesian approach, was previously reported by Dansirikul et al (17).

The change in value of $k_{a}$ was not observed, which was expected for sparse data, not containing any information about absorption. Some changes in posterior medians and tightening of posterior distribution were observed for parameters of distribution. The prior medians of $\mathrm{Vc} / \mathrm{F}, \mathrm{Vp} / \mathrm{F}$ and $\mathrm{Q} / \mathrm{F}(95 \% \mathrm{Cl})$ were 117 (99.4 - 138) L, 583 (459 - 736) L and 20.4 $(13.1-32.4) \mathrm{L} / \mathrm{h}$, compared to posterior values of 118 (113.0 - 122.9) L, 609 (533 - 685) L and 5.07 $(0.209-9.93) \mathrm{L} / \mathrm{h}$, respectively. This proposes that although data were sparse, obtained during routine TDM, they were informative for distribution parameters. Nevertheless, we were interested in the evaluation of CL/F and explanation of its variability due to its importance in dose individualization.

The typical $\mathrm{CL} / \mathrm{F}$ value in our model was estimated at $12.2 \mathrm{~L} / \mathrm{h}$, which is consistent with previous findings $(17,18)$. Our results showed that sirolimus $\mathrm{CL} / \mathrm{F}$ depends on age and liver function. Inclusion of these covariates described about $14 \%$ of interindividual variability.

Previous results have shown that total cholesterol and sirolimus doseaffected sirolimus CL/F (18). In the study of Jiao et al. CL/F decreased significantly with increasing total cholesterol level (18). Due to small inherent differences in the included population (Table I), we did not detect these covariates as significant in our study. Nevertheless, the nonlinear relation between sirolimus $\mathrm{CL} / \mathrm{F}$ and dose is the most likely due to TDM effect as explained by Ahn et al $(18,32)$. During the TDM process, the correlation between dose and CL/F occurs because doses are adjusted to obtain concentrations in the desired therapeutic range, so it is not recommended to model $\mathrm{CL} / \mathrm{F}$ as a function of dose when data are obtained from TDM, as is the case in our study (32).

According to our final model, sirolimus $\mathrm{CL} / \mathrm{F}$ decreases with age which complies with the previously published work (17). In our population $24 \%$ of patients were younger than 30 years and 32\% were 50 years and older, so age distribution was adequate for its influence analysis. Change in CL/F between the youngest (16 years) and the oldest patient ( 64 years) included in this study was approximately $49 \%$.This, quite significant influence of age could be partly attributed to the well-known decline in a number of physiological processes with age. Therefore, further researches are necessary for confirmation and explanation of this influence.
Our final model suggested the negative relation between $\mathrm{CL} / \mathrm{F}$ and liver function, expressed as AST above upper margin of $37 \mathrm{IU} / \mathrm{L}$. As sirolimus is a highly metabolized drug, this relationship is expected, and it is consistent with the results of previously published studies $(13,14)$. Unlike kidney function, where biochemical parameter exists and adequately describes renal impairment, and at the same time correlates with drugs elimination capacity, appropriate marker for hepatic function is not well-established (33). During the model building process, our preliminary results indicated significant correlation among AST, ALT and ALP, but according to the highest drop in OFV, AST showed the most significant influence on sirolimus CL/F. The enzyme AST is frequently used in population pharmacokinetic models (34-36), representing a quantitative parameter of liver function, and covariate for drug's liver clearing. AST was included in the final model as categorical covariate (reference versus elevated values). According to our model, sirolimus CL/F decreased in average by $37 \%$ in kidney transplant patients with compromised liver function. In the study by Zimmerman et al. sirolimus $\mathrm{CL} / \mathrm{F}$ was significantly decreased in subjects with mild and moderate hepatic impairment by $31.8 \%$ and $36.0 \%$, respectively, compared with controls consisting of healthy subjects (13). According to sirolimus Summary of Product Characteristics, in mild and moderate hepatically impaired patients (based on Child-Pugh classification), CL/F decreases 33\% compared to healthy adult subjects (2). To our knowledge, this is the first population pharmacokinetic study using nonlinear mixed effects modeling which described and quantified the influence of liver function enzyme on sirolimus elimination in kidney transplant patients. Our results showed that AST, a routinely monitored liver enzyme, could be used in predicting the highly metabolized drug's elimination capacity. Results of our study suggest that patients with compromised liver function, expressed by elevated AST values, require careful sirolimus monitoring and accordingly dosing adjustments.

The scatter plots of CWRES vs. population predicted concentration (Figure 1) showed that the CWRES were mostly randomly distributed and lay within \pm 3 units of the null ordinate. The predictive performance of the model was assessed by internal and external validation techniques. NPC and pvcVPC showed the good predictive performance of the model (Figures 2 and 3). The mean parameter estimations obtained with bootstrap samples were not statistically different from those obtained with the original dataset (Table IV) indicating accuracy and robustness of the final population model. External validation also confirmed unbiased and precise prediction of sirolimus concentrations. This study is the first one that externally confirmed the possibility of using informative priors in developing population pharmacokinetic model of sirolimus with satisfactory predictive performances. 
In this study, a rather small number of patients were included, as sirolimus represents the second line drug according to the local immunosuppressive protocol. This was retrospective study, and all data were obtained during TDM, hence we analyzed multiple trough concentrations. Regardless the aforementioned limitations of the nature of data, accurate estimation and efficient covariate detection, as well as quantification of covariates' influences on sirolimus $\mathrm{CL} / \mathrm{F}$ could be achieved. This study reveals that TDM sparse data could be enough informative for the development of quite a complex model. Hence, our study results support the feasibility to estimate sirolimus individual pharmacokinetic parameters from such study design while integrating the prior information. The part of the variability in sirolimus $C L / F$ is explained with demographic and routinely monitored parameters. Remaining variability in our model could be attributed to pharmacogenetic data. Djebli at al. found a significant influence of the CYP3A5*1/*3 polymorphism on sirolimus CL/F (19), so it would be valuable, during further work, to assess the impact of genetic polymorphism in our population. However, pharmacogenetic analyses have not been yet part of routine monitoring in transplant centers so the inclusion of this covariate could reduce usefulness and possibility of model application in everyday clinical practice.

\section{References}

1. Johnson $H$, Schonder, KS. Solid-organ Transplantation In: DiPiro J, Talbert, RL, Yee, GC, Matzke, GR, Wells, BG, Posey, LM, editor. Pharmacotherapy: A Pathophysiologic Approach. Eighth ed. New York: The McGraw-Hill Companies, Inc.; 2011: 1537-59.

2. Pfizer (2013) Summary of Product Characteristics for Rapamune.

3. Kahan BD. Sirolimus: a new agent for clinical renal transplantation. Transplant Proc 1997; 29: 48-50.

4. Đorđević-Catić A, Cvetković T, Stefanović N, VeličkovićRadovanović R. Current biochemical monitoring and risk management of immunosuppressive therapy after transplantation. J Med Biochem 2017; 36: 1-7.

5. Mahalati K, Kahan BD. Clinical pharmacokinetics of sirolimus. Clin Pharmacokinet 2001; 40: 573-85.

6. Lampen A, Zhang Y, Hackbarth I, Benet LZ, Sewing KF, Christians $U$. Metabolism and transport of the macrolide immunosuppressant sirolimus in the small intestine. J Pharmacol Exp Ther 1998; 285: 1104-12.

7. Sattler M, Guengerich FP, Yun CH, Christians U, Sewing KF. Cytochrome P-450 3A enzymes are responsible for biotransformation of FK506 and rapamycin in man and rat. Drug Metab Dispos 1992; 20: 753-61.

8. Zimmerman JJ, Kahan BD. Pharmacokinetics of sirolimus in stable renal transplant patients after multiple
We demonstrated feasibility to explain partial of pharmacokinetic variability and to estimate sirolimus individual pharmacokinetic parameters using the population pharmacokinetic model based on sparse TDM data, with the use of routinely measured biochemical and clinical parameters as covariates. Proven good predictive performance makes this model a useful tool in individualization of the sirolimus dosing regimen in adult kidney transplant patients during routine clinical practice.

Acknowledgments. This work was conducted as a part of the project Experimental and Clinical Pharmacological Investigations of Mechanisms of Drug Action and Interactions in Nervous and Cardiovascular System (No. 175023), funded by Ministry of Education, Science and Technological Development, Belgrade, Republic of Serbia.

We are very grateful to the medical team from Nephrology Clinic, Clinical Center of Serbia, University of Belgrade, Republic of Serbia for their assistance.

\section{Conflict of interest statement} interest.

The authors stated that they have no conflicts of interest.

oral dose administration. J Clin Pharmacol 1997; 37: 405-15.

9. Brattstrom C, Sawe J, Jansson B, Lonnebo A, Nordin J, Zimmerman JJ, et al. Pharmacokinetics and safety of single oral doses of sirolimus (rapamycin) in healthy male volunteers. Ther Drug Monit 2000; 22: 537-44.

10. Brattstrom C, Sawe J, Tyden G, Herlenius G, Claesson K, Zimmerman J, et al. Kinetics and dynamics of single oral doses of sirolimus in sixteen renal transplant recipients. Ther Drug Monit 1997; 19: 397-406.

11. Leung LY, Lim HK, Abell MW, Zimmerman JJ. Pharmacokinetics and metabolic disposition of sirolimus in healthy male volunteers after a single oral dose. Ther Drug Monit 2006; 28: 51-61.

12. Zimmerman JJ, Ferron GM, Lim HK, Parker V. The effect of a high-fat meal on the oral bioavailability of the immunosuppressant sirolimus (rapamycin). J Clin Pharmacol 1999; 39: 1155-61.

13. Zimmerman JJ, Lasseter KC, Lim HK, Harper D, Dilzer SC, Parker V, et al. Pharmacokinetics of sirolimus (rapamycin) in subjects with mild to moderate hepatic impairment. J Clin Pharmacol 2005; 45: 1368-72.

14. Zimmerman JJ, Patat A, Parks V, Moirand R, Matschke K. Pharmacokinetics of sirolimus (rapamycin) in subjects with severe hepatic impairment. J Clin Pharmacol 2008; 48: 285-92. 
15. Tejani A, Alexander S, Ettenger R, Lerner G, Zimmerman $J$, Kohaut E, et al. Safety and pharmacokinetics of ascending single doses of sirolimus (Rapamune, rapamycin) in pediatric patients with stable chronic renal failure undergoing dialysis. Pediatr Transplant 2004; 8: 151-60.

16. Ferron GM, Mishina EV, Zimmerman JJ, Jusko WJ. Population pharmacokinetics of sirolimus in kidney transplant patients. Clin Pharmacol Ther 1997; 61: 416-28.

17. Dansirikul C, Morris RG, Tett SE, Duffull SB. A Bayesian approach for population pharmacokinetic modelling of sirolimus. Br J Clin Pharmacol 2006; 62: 420-34.

18. Jiao Z, Shi XJ, Li ZD, Zhong MK. Population pharmacokinetics of sirolimus in de novo Chinese adult renal transplant patients. Br J Clin Pharmacol 2009; 68: 47-60.

19. Djebli N, Rousseau A, Hoizey G, Rerolle JP, Toupance O, Le Meur $Y$, et al. Sirolimus population pharmacokinetic/pharmacogenetic analysis and bayesian modelling in kidney transplant recipients. Clin Pharmacokinet 2006; 45: 1135-48.

20. Architect System. Sirolimus package insert. Abbott Laboratories, 2009.

21. Beal S, Sheiner, LB, Boeckmann, AJ. NONMEM users guide. Ellicott City: Icon Development Solutions; 1989_ 2011.

22. Keizer RJ, Karlsson MO, Hooker A. Modeling and Simulation Workbench for NONMEM: Tutorial on Pirana, PsN, and Xpose. CPT Pharmacometrics Syst Pharmacol 2013; 2: e50.

23. Gisleskog PO, Karlsson MO, Beal SL. Use of prior information to stabilize a population data analysis. J Pharmacokinet Pharmacodyn 2002; 29: 473-505.

24. Bonate P. Pharmacokinetic-Pharmacodynamic Modeling and Simulation. New York: Springer; 2006. p 296-304.

25. Panjeta M, Tahirović I, Sofić E, Ćorić J, Dervišević A. Interpretation of erythropoietin and haemoglobin levels in patients with various stages of chronic kidney disease. J Med Biochem 2017; 36: 145-52.

26. Jonsson EN, Karlsson MO. Automated covariate model building within NONMEM. Pharm Res 1998; 15: 14638 .
27. Mould DR, Upton RN. Basic concepts in population modeling, simulation, and model-based drug development-part 2: introduction to pharmacokinetic modeling methods. CPT Pharmacometrics Syst Pharmacol 2013; 2: e38.

28. Parke J, Holford NH, Charles BG. A procedure for generating bootstrap samples for the validation of nonlinear mixed-effects population models. Comput Methods Programs Biomed 1999; 59: 19-29.

29. Karlsson MO, Savic RM. Diagnosing model diagnostics. Clin Pharmacol Ther 2007; 82: 17-20.

30. Bergstrand M, Hooker AC, Wallin JE, Karlsson MO. Prediction-corrected visual predictive checks for diagnosing nonlinear mixed-effects models. Aaps J 2011; 13: 143-51.

31. Milinković N, Ignjatović S, Šumarac Z, Majkić-Singh N. Uncertainty of measurement in laboratory medicine. J Med Biochem 2018; 37: 279-88.

32. Ahn JE, Birnbaum AK, Brundage RC. Inherent correlation between dose and clearance in therapeutic drug monitoring settings: possible misinterpretation in population pharmacokinetic analyses. Journal of Pharmacokinetics and Pharmacodynamics 2005; 32: 703-18.

33. EMA. Guideline on the evaluation of the pharmacokinetics of medicinal products in patients with impaired hepatic function. London, 2005.

34. Antignac M, Hulot JS, Boleslawski E, Hannoun L, Touitou $Y$, Farinotti $R$, et al. Population pharmacokinetics of tacrolimus in full liver transplant patients: modelling of the post-operative clearance. Eur J Clin Pharmacol 2005; 61: 409-16.

35. Golubovic B, Vucicevic K, Radivojevic D, Kovacevic SV, Prostran M, Miljkovic B. Total plasma protein effect on tacrolimus elimination in kidney transplant patients Population pharmacokinetic approach. Eur J Pharm Sci 2013; 52: 34-40.

36. Staatz CE, Willis C, Taylor PJ, Tett SE. Population pharmacokinetics of tacrolimus in adult kidney transplant recipients. Clin Pharmacol Ther 2002; 72: 660-9. 